Loyalitas Kreativitas
Aldi Masyarakat Kreatif

P-ISSN 2722-2101, E-ISSN 2722-4201

Program Studi Ekonomi Manajemen Universitas Pamulang

Jurnal LOKABMAS Kreatif Vol.02,No.01,Maret 2021 Hal.100-109

Email:jurnalkreatif.manajemen@gmail.com

\title{
MANAJEMEN PEMERINTAHAN DESA DALAM MENCAPAI KEUNGGULAN POTENSIAL DAN BERDAYA SAING
}

\author{
Heri Saputra, Syawaludin, Jamaludin, Udin Saprudin, Tarwijo \\ Dosen Prodi Manajemen Fakultas Ekonomi Universitas Pamulang
}

Email: dosen02299@unpam.ac.id ; dosen02298@unpam.ac.id ; dosen01038@unpam.ac.id ; dosen01800@unpam.ac.id ; dosen01476@unpam.ac.id

\begin{abstract}
ABSTRAK
Pengabdian ini berjudul Manajemen Pemerintahan Desa dalam Mencapai Keunggulan Potensial dan Berdaya Saing pada Kantor Kepala Desa Sukamanah, Rajeg Tangerang. Tujuan pengabdian ini adalah memberikan pemahaman dan edukasi kepada pamong desa dan Masyarakat di daerah Sukamanah Kecamatan Rajeg-Kabupaten Tangerang-Banten agar memahami dan menumbuhkan sikap peduli akan kemajuan serta perkembangan desa yang selama ini menjadi wilayah tempat tinggal dan mengembangkan usaha mereka agar selalu maju dan unggul pada potensi sumber Daya yang ada dan memiliki daya saing.

Metode pelaksanaan pengabdian ini dilakukan dalam beberapa kegiatan yaitu tahap survei yaitu sosialisasi dilakukan dengan menyusun berbagai hal yang akan disampaikan pada saat kegiatan pengabdian yang akan dilakukan yang meliputi: penyusunan materi yang akan diberikan, penyusunan jadwal pemberian materi, pembagian tugas tim pengabdian dan survei ke lokasi pengabdian. Tahap sosialisasi yaitu sebelum kegiatan pengabdian dilaksanakan terlebih dahulu dilakukan tahap sosialisasi yaitu melakukan silaturahmi dengan pihak kelurahan, menyampaikan maksud dan tujuan pengabdian ini. Pada tahap ini juga dilakukan jalinan kerjasama dan menentukan jadwal kegiatan pengabdian. Tim pelaksana kegiatan pengabdian pada masyarakat adalah dosen Fakultas Ekonomi jurusan manajemen sebanyak 5 orang dan 2 orang mahasiswa prodi manajemen. Tim pengabdian memberikan materi tentang Manajemen Pemerintahan Desa dalam Mencapai Keunggulan Potensial dan Berdaya Saing di daerah Sukamanah Kecamatan Rajeg-Kabupaten Tangerang-Banten.

Kesimpulan dari pengabdian ini adalah Para pamong desa dan masyarakat belum sepenuhnya memahami tentang keunggulan potensial dan daya saing desanya. Dengan adanya pemahaman tentang keunggulan potensial pada desa sukamanah dapat menumbuhkan sikap peduli akan kemajuan serta perkembangan desa yang selama ini menjadi wilayah tempat tinggal dan mengembangkan usaha mereka agar selalu maju dan unggul pada potensi sumber Daya yang ada dan memiliki daya saing
\end{abstract}

Kata Kunci: keunggulan potensial, berdaya saing

\section{ABSTRACT}

This devotion is titled Village Government Management in Achieving Potential And Competitive Excellence at the Sukamanah Village Head Office, Rajeg Tangerang. The purpose of this service is to provide understanding and education to the village pamong and the community in 
Loyalitas Kreativitas
Aldi Masyarakat Kreatif
P-ISSN 2722-2101, E-ISSN 2722-4201

Program Studi Ekonomi Manajemen Universitas Pamulang Jurnal LOKABMAS Kreatif Vol.02,No.01,Maret 2021 Hal.100-109

Email:jurnalkreatif.manajemen@gmail.com

sukamanah district of Rajeg-Tangerang-Banten regency in order to understand and foster a caring attitude to the progress and development of the village that has been a residential area and develop their business in order to always progress and excel at the potential of existing resources and have competitiveness.

The method of implementation of this devotion is carried out in several activities, namely the survey stage, namely socialization is carried out by arranging various things that will be delivered at the time of the service activities that will be carried out which include: the preparation of materials to be given, the preparation of the schedule of material delivery, the division of tasks of the service team and the survey to the location of devotion. The socialization stage is before the devotional activities are carried out first, namely conducting friendship with the village, conveying the purpose and purpose of this devotion. At this stage, cooperation is also carried out and determine the schedule of devotion activities. The implementation team of community service activities is a lecturer of the Faculty of Economics majoring in management as many as 5 people and 2 students of management study program. The dedication team provides material on Village Government Management in Achieving Potential and Competitive Excellence in sukamanah area of Rajeg SubDistrict- Tangerang-Banten Regency.

The conclusion of this devotion is that the village pamongs and the community have not fully understood about the potential advantages and competitiveness of the village. With an understanding of the potential advantages in sukamanah village can foster a caring attitude to the progress and development of villages that have been a residential area and develop their business to always progress and excel at the potential of existing resources and have competitiveness

Keywords: potential advantages, competitiveness

\section{PENDAHULUAN}

Dalam Undang-undang Republik Indonesia Nomor 6 tahun 2014 yang mengatur tentang Pemerintahan desa dan tata cara penyelenggaraan Pemerintahan dan pembangunan wilayah Desa. Dalam undang undang tersebut menjelaskan bahwa desa adalah desa dan desa adat atau yang disebut dengan nama lain, selanjutnya disebut Desa, adalah kesatuan masyarakat hukum yang memiliki batas wilayah yang berwenang untuk mengatur dan mengurus urusan pemerintahan,kepentingan masyarakat setempat berdasarkan prakarsa masyarakat, hak asalusul, dan/atau hak tradisionalyang diakui dan dihormati dalam sistem pemerintahan Negara Kesatuan Republik Indonesia.

Pada sistem pemerintahan yang kita kenal dengan Sistem pemerintahan Desa memiliki pengertian sebagai penyelenggaraan urusan pemerintahandan kepentingan masyarakat setempat dalam sistempemerintahan Negara
Kesatuan Republik Indonesia. Selanjutnya Pada prinsipnya tugas pokok penyelenggaraan pemerintah adalah public service, yaitu pelayanan atau melayani masyarakat. Terutama dalam pemerintahan desa, tingkat kemampuan pemerintah dengan tingkat kemampuan masyarakat moderen, tradisional maupun termodern sekalipun harus seimbang atau diimbangi. Disamping itu pemerintah des dituntut lebih banyak memberikan bimbingan, pembinaan serta motivasi mengejar ketertinggalan dari bagian masyarakat yang lain yang sudah maju, sehingga wajar apabila dalam kondisi seperti ini dibutuhkan government (pemerintah) dan governance (pemerintahan) yang memadai.

Kemampuan menyelenggarakan pemerintahan desa sangat ditentukan oleh kecakapan menajerial dari eksponen pemerintahan dan berfungsinya sistem manajemen. Pola penyelenggaraan pemerintahan desa di satu sisi harus mengikuti tuntutan modernitas, namun di sisi lain harus peka 
Loyalitas Kreativitas
Aldi Masyarakat Kreatif
P-ISSN 2722-2101, E-ISSN 2722-4201

Program Studi Ekonomi Manajemen Universitas Pamulang Jurnal LOKABMAS Kreatif Vol.02,No.01,Maret 2021 Hal.100-109

Email:jurnalkreatif.manajemen@gmail.com terhadap konteks budaya setempat. Dari tinjauan tersebut, apabila governance sudah berjalan dengan baik serta dalam tataran implementasinya telah mengakomodasi empat komponen yang meliputi : Hak azazi manusia (human right), masyarakat madani (civil society), demokratisasi dan globalisasi, maka kepemerintahan yang ada telah berkualifikasi baik atau diistilahkan "good governance".

Birokrasi Indonesia memiliki pengertian suatu sistem pemerintahan yang dijalankan oleh pegawai bayaran yang tidak dipilih oleh rakyat, cara pemerintahan yang sangat dikuasai oleh pegawai. Birokrasi pemerintah Indonesia memiliki peranan sebagai stabilisator (menciptakan suasana aman dan stabil); dinamisator (menggerakkan); inovator (pembaharuan); arbitrator dan moderator (perantara).

Selanjutnya selain penyelenggaraan sistem pemerintahan desa yang baik, suatu pemerintahan desa tentunya bisa memberikan kontribusi besar terhadap perkembangan perekonomian didesa, banyak potensi desa yang bisa kita kembangkan untuk kesejahteraan masyarakat pedesaan. Baik yang bersumber dari sumber daya alam dan sumber daya manusia itu sendiri. Potensi desa yang dimiliki oleh suatu desa menjadikan suatu desa tersebut mempunyai daya saing dengan desa lainya. Menurut Indri (2018:2) Potensi keunggulan daerah adalah keunggulan yang di miliki suatu daerah yang tidak dimiliki oleh daerah lain, sehingga keunggulan ini menjadi potensi menjanjikan dearah tersebut.

Aparatur dan pamong desa merupakan sarana pendukung kelancaran dan ketertiban pemerintahan desa. Peranannya sangat penting bagi perubahan dan tingkat perkembangan potesial desa yang baik. Misalkan : kepala desa, kepala dusun, kepala adat, jaro, ketua lingkungan dan lain-lain. Adapun tujuan pengembangan potensi desa adalah untuk mendorong terwujudnya kemandirian masyarakat Desa/Kelurahan melalui Pengembangan Potensi Unggulan dan Penguatan Kelembagaan serta Pemberdayaan Masyarakat. Selain itu Upaya memberdayakan potensi desa perlu terus dilakukan agar kualitas kehidupan di desa lebih baik. Dengan demikian sumberdaya di desa, baik sumber daya manusia maupun sumber daya alam sangat potensial untuk meningkatkan kesejahteraan masyarakat. Jika dikelola dengan baik, maka desa dapat mencapai tingkat kemajuan yang dicita-citakan. Maka PKM ini mengangkat sebuah tema "Manajemen Pemerintahan Desa Dalam Mencapai Keunggulan Potensial Dan Berdaya Saing”.

\section{RUMUSAN MASALAH}

Berdasarkan latar belakangdi atas, dapat dirumuskan masalahnya sebagai berikut:

1. Bagaimana Manajemen Pemerintahan Desa Sukamanah Kec. Rajeg Kab. Tangerang ?

2. Bagaimana Potensi Sumber Daya di Desa Sukamanah Kec. Rajeg Kab. Tangerang ?

3. Bagaimana Mencapai Keunggulan Potensial dan Berdaya Saing Desa Sukamanah Kec. Rajeg Kab. Tangerang ?

\section{TUJUAN PELAKSANAAN}

Tujuan dari PKM ini adalah:

1. Untuk memberikan penyuluhan tentang bagaimana manajemen yang baik di kantor Desa Sukamanah

2. Untuk mengetahui potensi sumber daya yang ada di desa sukamanah

3. Untuk mengetahuin bagaimana cara desa Sukamanah untuk mencapai keunggulan potensial dan berdaya saing

\section{TINJAUAN PUSTAKA}

\section{Manajemen Pemerintahan Desa}

Pada pasal 1 Ayat (2) menyatakan Pemerintahan Desa adalah penyelenggaraan urusan pemerintahan dan kepentingan masyarakat setempat dalam sistem pemerintahan Negara Kesatuan Republik Indonesia. Pada penjelasan selanjutnya Ayat (3) Pemerintah Desa adalah Kepala Desa atau yang disebut dengan nama lain dibantu 
Loyalitas Kreativitas
Aldi Masyarakat Kreatif
P-ISSN 2722-2101, E-ISSN 2722-4201

Program Studi Ekonomi Manajemen Universitas Pamulang

Jurnal LOKABMAS Kreatif Vol.02,No.01,Maret 2021 Hal.100-109

Email:jurnalkreatif.manajemen@gmail.com perangkat Desa sebagai unsur penyelenggara Pemerintahan Desa. Menurut Undang-undang nomor 22 tahun 1999 Desa adalah kesatuan masyarakat hukum yang memiliki kewenangan untuk mengatur dan mengurus kepentingan masyarakat setempat berdasarkan asal-usul dan adat istiadat setempat yang diakui dalam sistem pemerintahan Nasional dan berada di daerah Kabupaten.

Menurut Bintarto (2018) Desa adalah perwujudan geografis yang ditimbulkan oleh unsur-unsur fisiografis, sosial, ekonomis politik, kultural setempat dalam hubungan dan pengaruh timbal balik dengan daerah lain. Menurut Rifhi Siddiq Desa adalah suatu wilayah yang memiliki tingkat kepadatan rendah yang dihuni oleh penduduk dengan interaksi sosial yang bersifat homogen, bermata pencaharian di bidang agraris dan juga mampu berinteraksi dengan wilayah lain di sekitarnya.

Menurut Sutardjo Kartodikusumo (2018) Desa adalah suatu kesatuan hukum dimana bertempat tinggal suatu masyarakat yang berkuasa mengadakan pemerintahan sendiri, dan ditambahkan Saniyati Nurmuharimah (2018), Desa adalah wilayah yang dihuni oleh masyarakat yang memiliki sistem pemerintahan sendiri. Sedangkan menurut Paul H. Landis (2018) memberikan ciri-ciri yang melekat pada masyarakat desa yang terbagi dari yang pertama, mempunyai pergaulan hidup yang saling kenal mengenal antar ribuan jiwa, yang kedua desa terdapat pertalian perasaan yang sama tentang kesukuan terhadap kebiasaan, yang ketiga desa merupakan cara atau tempat berusaha (ekonomi) memiliki makna agraris yang paling umum yang sangat dipengaruhi alam sekitar seperti iklim, keadaan alam, kekayaan alam, sedangkan pekerjaan yang bukan agraris adalah bersifat sambilan.

Dari uraian di atas mengenai pengertian Desa dan Pemerintahan Desa, penulis dapat memberikan kesimpulan atas kedua pengertian diatas. Yang pertama Desa adalah kesatuan masyarakat hukum yang memiliki batas wilayah yang berwenang untuk mengatur dan mengurus urusan pemerintahan, kepentingan masyarakat setempat berdasarkan prakarsa masyarakat, hak asalusul, dan/atau hak tradisional yang diakui dan dihormati dalam sistem pemerintahan Negara Kesatuan Republik Indonesia. Yang kedua Pemerintahan Desa adalah adalah penyelenggaraan urusan pemerintahan dan kepentingan masyarakat setempat dalam sistem pemerintahan Negara Kesatuan Republik Indonesia. Dalam hal ini penyelengara Pemerintahan Desa adalah Pemerintah Desa atau kita kenal dengan Kepala Desa.

\section{Keunggulan Potensi Desa}

Potensi dalam kegiatan Pengabdian Kepada Masyarakat ini adalah daya, kekuatan, kesanggupan dan kemampuan yang mempunyai kemungkinan untuk dapat dikembangkan. Dalam artikel dan berita oleh Admin Desa Klutuk (2019) Potensi Desa merupakan segala sumber daya alam maupun sumber daya manusia yang terdapat serta tersimpan di desa Jadi Potensi desa adalah segala sumber daya alam maupun sumber daya manusia yang terdapat serta tersimpan di desa yang mempunyai kemungkinan untuk dapat dikembangkan dalam rangka meningkatkan kesejahteraan masyarakat. Secara garis besar potensi desa dapat dibedakan menjadi dua yakni:

\section{a. Potensi Fisik}

Potensi fisik yang berkaitan dengan Sumber Daya yaitu tanah, air, iklim, lingkungan geografis, binatang ternak, dan sumber daya manusia.

\section{b. Potensi Non-fisik}

Potensi nonfisik merupakan potensi yang berkaitan erat dengan sumber daya budaya masyarakat desa. Potensi nonfisik bisa kita jumpai berupa aktitivitas masyarakat dengan corak dan interaksinya, lembagalembaga sosial, lembaga pendidikan, dan 
Loyalitas Kreativitas
Aldi Masyarakat Kreatif

organisasi sosial desa, serta aparatur dan pamong desa. segala potensi yang berkaitan dengan masyarakat desa dan tata perilakunya. Potensi non fisik lainnya adalah lembaga desa, aparatur desa, adat istiadat dan budaya. Suatu masyarakat desa yang hidup dalam waktu yang lama akan membentuk tata kehidupan tersendiri. Tata kehidupan akan dipengaruhi oleh kondisi alam wilayah desa itu sendiri.

\section{c. Daya saing Desa}

Keunggulan dan daya saing Desa adalah bagian terpenting yang dimiliki oleh suatu desa, suatu keunggulan masyarakat desa adalah dalam hal memenuhi permintaan masyarakatnya dalam bidang-bidang yang menjadi potensi desa. Keunggulan dan daya saing inilah yang menjadikan desa berbeda dengan desa lainnya.

\section{METODE PELAKSANAAN}

\section{Sasaran Program}

Prinsip pemberdayaan masyarakat yang paling baik adalah kelompok yang lahir dari kebutuhan dan kesadaran masyarakatnya sendiri, dikelola, dan dikembangkan dengan menggunakan terutama sumber daya yang ada di masyarakat tersebut, dan memiliki tujuan yang sama. Dosen sebagai manusia yang berintelektual tinggi diharapkan bisa memberikan kontribusi yang tidak hanya dalam bentuk materi, tetapi juga dalam bentuk moril. Kontribusi moril ini diharapkan dapat memotivasi masyarakat dalam menghadapi setiap tantangan hidup, seperti yang terjadi di era globalisasi sekarang ini.

Mahasiswa juga sebagai generasi muda yang peduli terhadap kesejahteraan bangsa dan penerus tongkat estafet mempunyai tanggung jawab atas kelangsungan generasi dari perkembangan bangsa yang akan datang. Semuanya tidak terlepas dari dukungan dan kerjasama dari setiap elemen masyarakat yang ada di dalamnya dengan tujuan untuk kemajuan bangsa.

Berdasarkan dari latar belakang tersebut, kami dari Tim PkM dengan judul: "Manajemen Pemerintahan Desa dalam Mencapai Keunggulan Potensial dan Berdaya Saing " terpanggil untuk ikut serta memberikan edukasi kepada pamong desa dan Masyarakat mengenai Keunggulan potensial desa. Sasaran program Pengabdian Kepada Masyarakat adalah pegawai di Kelurahan Sukaman dan Masyarakat Desa Sukamanah, kecamatan Rajeg, Tangerang.

\section{Metode Kegiatan}

Metode kegiatan yang digunakan kepada pengunjung adalah dengan memberikan penjelasan materi teori terlebih dahulu baru kemudian peragaan. Berikut ini adalah tahapan kegiatan yang dilakukan:

a. Tahap Persiapan Adapun tahap-tahap yang dilakukan dalam kegiatan ini meliputi:

1) Survei awal Pada tahap ini dilakukan survei ke lokasi kelurahan pondok benda.

2) Fiksasi Jadwal Pada tahap ini dilakukan penentuan waktu kegiatan.

3) Persiapan Materi Kegiatan Pada tahap ini dilakukan penyusunan bahan/materi kegiatan yang meliputi: slide powerpoint dan handout

4) Persiapan Peragaan Pada tahap ini dilakukan persiapan alat dan bahan untuk peragaan .

b. Tahap Pelaksanaan Kegiatan.

Untuk melaksanakan kegiatan ini digunakan 3 metode, yaitu:

1) Metode Penjelasan Teori Sederhana Memberikan penjelasan singkat dan sederhana konsep

2) Metode Peragaan Melakukan peragaan insitu

3) Diskusi Melakukan diskusi dengan stake holder Desa Sukamanah untuk membuka wawasan 


\section{Waktu dan Lokasi}

\section{a. Waktu}

Pelaksanaan dilakukan pada tanggal 10 12 November 2020, dari pukul 10.00. sampai dengan pukul 13.00 WIB. Dihadiri oleh Pengurus Kelurahan Sukamanah.

\section{b. Lokasi}

Lokasi yang dipilih dalam kegiatan PkM ini adalah Kelurahan Desa Sukamanah, Rajeg Tangerang

\section{Metode}

Metode kegiatan Pengabdian Masyarakat di desa Sukamanah yang disampaikan melalui workshop dan pelatihan dari para dosen sebagai narasumber ke beberapa aparatur desa atau pamong Desa dengan menggunakan protokol kesehatan Covid 19. Adapun peserta ynag hadir pada acara pengabdian Masyarakat ini adalah semua elemen pamong desa, pelaku usaha, perwakilan tokoh masyarakat, ketua Rukun Tetangga (RT), Ketua Rukun Warga (RW) dan elemen desa lainnya. Selain melakukan workshop dan pelatihan kami pun melakukan wawancara langsung kepada kepala desa dan sekretaris desa dan para aparatur yang butuhkan untuk Tenaga Pengajar/Guru tersebut. Adapun tahapan-tahapan yang kami lakukan dalam menunjang dalam kegiatan Pengabdian Kepada Masyarakat ini diantaranya kami memberikan workshop dan pelatihan kepada Pemerintahan Desa Sukamanah untuk menyampaikan kepada mereka betapa pentingnya menjalankan Pemerintahan Desa yang baik, bagaimana potensi desa, dan daya saing desa. Melalui whorshop dan pelatihna ini, dapat memberikan khasanah keilmuan baik dari dosen, praktisi pemerintahan dan akademisi kepada audience dalam hal ini adalah Pemerintahan Desa Sukamanah yang membutuhkan akan informasi dan khasanah keilmuan.

\section{PEMBAHASAN}

Daya Saing di Desa Sukamanah, masyarakat dan tokoh memberikan pernyataan akan upaya dan langkah-langkah memajukan perekonomian usaha baik perorangan maupun usaha bersama. Desa sebagai wilayah yang bertumpu pada potensi lokal, terutama perekonomian berbasis pertanian dan UMKM di tengah pertumbuhan industri global, sehingga membutuhkan perhatian khusus sebagaimana amanat Undang-Undang Nomor 6 Tahun 2014 terutama Bab IX Pasal 78 yang menyatakan bahwa:

1. Pembangunan desa bertujuan meningkatkan kesejahteraan masyarakat desa dan kualitas hidup manusia serta penanggulangan kemiskinan melalui pemenuhan kebutuhan dasar, pembangunan sarana dan prasarana Desa, pengembangan potensi ekonomi lokal, serta pemanfaatan sumber daya alam dan lingkungan secara berkelanjutan.

2. Pembangunan desa meliputi tahap perencanaan, pelaksanaan, dan pengawasan.

3. Pembangunan desa sebagaimana dimaksud pada ayat (2) mengedepankan kebersamaan, kekeluargaan, dan kegotongroyongan guna mewujudkan pengarusutamaan perdamaian dan keadilan sosial.

Di desa Sukamanah Ada Beberapa Program yang dijalankan sesuai dengan Program Pembangunan Berkelanjutan dalam memperbaiki infrastruktur, aksesabilitas pedesaan:

1. Pembangunan Rumah Subsidi Oleh Pemerintahan Daerah melalui kerja sama dengan berbagai Deplover.

2. Pembangunan Jembatan Desa Sumur Daon dan Jembatan Gembong merupakan Akses Desa Besar.

3. Perencanaan Sanitasi dan Penyediaan Air minum Bersih dengan Dinas Terkait untuk wilayah perumahan dan kampung. 
Loyalitas Kreativitas
Aldi Masyarakat Kreatif
P-ISSN 2722-2101, E-ISSN 2722-4201

Program Studi Ekonomi Manajemen Universitas Pamulang

Jurnal LOKABMAS Kreatif Vol.02,No.01,Maret 2021 Hal.100-109

Email:jurnalkreatif.manajemen@gmail.com
4. Pengairan Irigasi Secara berkelanjutan untuk memenuhi kebutuhan air sawah, dan kebutuhan rumah tangga lainnya

Beberapa Program yang dijalankan sesuai dengan Program Pembangunan Berkelanjutan dalam Bidang Pertanian Desa Sukamanah:

1. Pelatihan Penyuluhan Pertanian Lapangan (PPL) Kec. Rajeg Kepada Para petani Desa.

2. Bimbingan Teknis Bertani dari Dinas Pertanian Kabupaten Tangerang.

3. Pelatihan dan Tanam benih padi di daerah kampung Cakop-Jawa ringan.

Beberapa Program yang dijalankan sesuai dengan Program Pembangunan Berkelanjutan dalam Bidang Peternakan Desa Sukamanah:

1. Pembibitan atau Budidaya Ikan Lele

2. Pemberian Bantuan Budidaya Ayam Joper 1000 Ekor (50 Ekor/kk)

3. Budidaya Kambing (Perencaaan) tertunda saat Covid- 19.

Banyak permasalahan desa saat ini yang menjadi pekerjaan rumah bagi pemerintahan desa. Terutama desa yang penulis teliti lebih jauh. Dengan memberikan solusi kepada desa Sukamanah dengan memberikan strategi untuk memecahkan permasalahan. Hal itu menegaskan bahwa dalam setiap masalah harus dapat dipecahkan dengan menggunakan strategi yang tepat, sedapat mungkin dengan cara yang sederhana, dapat dijangkau dengan mudah, dapat dipertanggung jawabkan, dan memiliki dimensi waktu yang jelas.

Solusi Strategis atas peningkatan Daya Saing di desa Sukamanah Karena itu membangun desa harus dimulai dari mempersempit disparitas kota-desa secara terukur dan tepat agar dapat menjamin kepastian keberhasilan, yakni, Mempercepat pembangunan infrastruktur Desa memerlukan strategi yang tepat, Jumlah penduduk miskin berpengetahuan rendah yang dominan di perdesaan perlu strategi dalam melibatkan masyarakat perdesaan dalam pembangunan infrastruktur perdesaan sehingga bisa memberikan beberapa dampak, antara lain:
1. Kualitas pekerjaan yang dihasilkan,

2. Keberlangsungan operasional dan pemeliharaan infrastruktur tersebut,

3. Kemampuan masyarakat dalam membangun suatu kemitraan dengan berbagai pihak, serta

4. Penguatan kapasitas masyarakat untuk mampu mandiri memfasilitasi kegiatan masyarakat dalam wilayahnya.

Misalnya di bidang pertanian dan peternakan, mereka dikenalkan berbagai peluang usaha dari pertanian dan peternakan beserta cara pengelolaannya dengan managemen yang baik, strategi peningkatan hasil pertanian dan penggunaan pupuk dan bahan kimia yang tepat. Untuk Pembinaan tukang dan pengrajin, mereka perlu mempelajari ketrampilan dasar menjadi pengrajin, dikenalkan berbagai bahan dasar, proses pembuatan sampai pada pemasaran, bahkan penggunaan alat-alat pertukangan modern dan perawatannya sehingga pembuatan kerajinan lebih cepat dan lebih baik. Dalam hal pembinaan Industri kecil, SDM Desa perlu dikenalkan berbagai jenis usaha kecil seperti makanan, souvenir, hiasan rumah, peralatan sehari-hari terutama yang memeiliki ketersediaan bahan baku di daerah tersebut.

Mulai dari cara pembuatan, mengemas agar menarik dan pemasaran juga perlu di sampaikan Meningkatkan kapasitas Iptek Desa tak terlepas dari adanya hubungan IPTEK dan kemiskinan. Ilmu pengetahuan, teknologi dan kemiskinan memiliki kaitan struktur yang jelas. Ilmu pengetahuan dan teknologi merupakan dua hal yang tak terpisahkan dalam peranannya untuk memenuhi kebutuhan insani. Ilmu pengetahuan digunakan untuk mengetahui "apa" sedangkan teknologi mengetahui "bagaimana". Ilmu pengetahuan sebagai suatu badan pengetahuan sedangkan teknologi sebagai seni yang berhubungan dengan proses produksi, berkaitan dalam suatu sistem yang saling berinteraksi. Teknologi merupakan penerapan ilmu pengetahuan, sementara teknologi mengandung 
Loyalitas Kreativitas
Aldi Masyarakat Kreatif
P-ISSN 2722-2101, E-ISSN 2722-4201

Program Studi Ekonomi Manajemen Universitas Pamulang

Jurnal LOKABMAS Kreatif Vol.02,No.01,Maret 2021 Hal.100-109

Email:jurnalkreatif.manajemen@gmail.com ilmu pengetahuan di dalamnya. Perubahan teknologi yang cepat dapat mengakibatkan perubahan struktur dan pola kemiskinan, karena terjadi perubahan sosial yang fundamental.

Memperkuat skema pelatihan Pengusaha Pemula Berbasis Teknologi yang bertujuan untuk mendukung kewirausahaan berbasis teknologi untuk masyarakat Desa. Perusahaan pemula yang dikembangkan, memanfaatkan hasil penelitian dan pengembangan dari lembaga litbang maupun perguruan tinggi. Selain itu juga bertujuan untuk meningkatkan kapasitas inkubator-inkubator yang saling terhubung dan bekerja sama satu sama lain untuk mengembangkan, membangun sinergi dan membantu industri serta Industri Kecil Menengah terutama dalam menyesuaikan teknologi-teknologi yang tepat. Jenius bantuan yang disediakan mencakup on-site dan offsite melalui jasa pelatihan dan pendampingan, serta mengembangkan materi-materi intermediasi melalui kerjasama dengan organisasi-organisasi terkait. Dalam proses inkubasi ini, umumnya pengusaha pemula diberikan: mentoring, pendampingan uji produksi, pendampingan uji konsumen, pendampingan uji jual, sertifikasi, hingga promosi.

Membangun kerjasama terutama pasar bagi komoditas desa, terutama jika dikaitkan dengan realitas pasar desa, yaitu bahwa komoditas paling banyak adalah barang-barang hasil bumi yang siap untuk dikonsumsi. Seperti sayur-sayuran, hasil panen, alat-alat produksi, makanan siap makan (jenang, gudeg, gorengan, dan makanan khas daerah setempat). Meski demikian, dalam dua decade terakhir ini banyak pasar desa yang juga menyediakan komoditas sandang/pakaian. Barang komoditas seperti perkakas/ peralatan pertanian dan barang-barang modal dalam proses produksi yang juga disediakan di pasar adalah konsekuensi logis dari mayoritas profesi masyarakat desa sebagai petani. Karena desa sebagian besar menjual komoditas hasil pertanian maka Time delivery sangat penting untuk diperhatikan disamping kualitas barang dan harga. Oleh karenanya menual barang dengan cepat, kualitas prima dan harga bersaing menjadi parameter utama yang harus diperhatikan dalam pola kerjasama pasar komoditas desa.

Tidak menutup kemungkinan jika beberapa hal diatas dilakukan, yaitu antara lain adalah membangun SDM Desa Sukamanah, membekali masyarakat Desa Sukamanah dengan Iptek, membangun Pasar Desa serta mendorong tumbuhnya Pengusaha Pemula Desa yang berbasis teknologi maka ekonomi desa akan tumbuh produktif dan terjadi lompatan pendapatan yang tinggi. Pada gilirannya Desa akan memiliki kekuatan dan daya saing yang dapat memberikan dampak pada daya saing nasional.

\section{KESIMPULAN DAN SARAN}

\section{Kesimpulan}

Berdasarkan hasil analisa yang diperoleh dari observasi, wawancara dan studi lapangan maka peneliti dapat menarik kesimpulan bahwa Manajemen Pemerintahan Desa Sukamanah Dalam Mencapai keunggulan Potensial dan Berdaya Saing, ada beberapa keunggulan yang dicapai dan ada juga beberapa kekurangannya, antara lain sebagai berikut:

1. Untuk Pelayanan yang tepat guna dan sasaran kepada warga yang mengurus Domisili, Keterangan pindah, izin menikah,izin usaha dan lainnya.

2. Semua bentuk pelaporan dan data keuangan terpublikasi dengan baik kepada masyarakat umum dan pemeritah kecamatan serta Pemerintah Kabupaten.

3. Pemerintahan Desa Yang aktif dan transparan dalam berbagai kegiatan

Sedangkan untuk kekurangan dari Desa Sukamanah melalui penelitian lapangan antara lain sebagai berikut:

1. Rendahnya Tingkat kualitas Sumber Daya Manusia (SDM) Desa sehingga belum bisa menopang dan menjadi mitra Pemerintahan Desa.

2. Rendahnya kualitas SDM sehingga kurang memahami aspek peduli terhadap lingkungan. 
3. Lembaga pendidikan yang semestinya menjadi media untuk mencetak SDM yang baik dan unggul serta berkarakter belum berjalan sebagaimana mestinya.

4. Program Ekonomi Desa yang belum jelas dan belum berjalan dengan baik.

5. Belum ada pemetaan yang jelas mengenai SDM yang dimiliki oleh desa Sukamanah

\section{Saran}

\section{Bagi Desa Sukamanah}

Dari hasil penelitian yang telah kami lakukan di Desa Sukamanah Berikut ini saran yang dapat penulis berikan berdasarkan temuantemuan dari hasil penelitian.

a. Desa berdasarkan perundang-udangan selayaknya mendirikan Pasar Desa untuk medukung roda perekonomian Masyarakat Desa.

b. Dalam Aspek Pemenuhan Sanitasi diperlukannya sinergitas semua elemen untuk menjalankan program Desa Sukamanah yang melimpah dan kecukupan akan air sanitasi.

c. Diperlukannya kerja sama antar elemen baik masyarakat dan perangkat desa dalam Menjalankan program UMKM Desa.

d. Untuk menunjang kemampuan dan keterampilan SDM Desa Maka diperlukannya Pelatihan dan Penyuluhan.

e. Lembaga Pendidikan seyogyanya untuk mencetak SDM yang berkualitas perlu adanya sinergitas antara Penyelenggara Pendidikan dengan Masyarakat Desa serta perlu pendekatan dan pengawasan Oleh Pemerintahan Desa.

f. Perpustakaan Desa untuk mencerdaskan SDM Masyarakat Desa Sukamanah.

g. Semua aparat harus banyak belajar mengenai teknologi, karena sedikit banyak arus informasi diserap atau disalurkan melalui teknologi, dalam hal ini dunai internet.

\section{DAFTAR PUSTAKA}

Ahmad Soleh, 2017. "Strategi Pengembangan Potensi Desa " Universitas Padjajaran Jurnal Sungkai Vol.5 No.1, Edisi Februari 2017 Hal : $32-52$

Angga Murjana, 2019; Wikipedia Bahasa Indonesia, Ensiklopedia Bebas (2019)."Pengertian Desa Menurut Para Ahli Serta Fungsi Ciri-Ciri Desa "http://id.wikipedia.org/wiki/De $\underline{\text { sa. }}$.(diakses 18 Oktober 2019).

A. Sahi Nirmala, 2018. "Peningkatan Kualitas Perangkat Desa Guna Pemantapan Pelaksanaan Pembangunan di Desa Ilotedia Kabupaten Gorontalo”.Jurnal Of Public Administration Studies, Vol.1- No. 1April 2018 P-ISSN: 2614-2112 E- ISSN: 2614-2090.

Bintarto,R. Wikipedia Bahasa Indonesia, Ensiklopedia Bebas. (2014), dari http://id.wikipedia.org/wiki/Desa.(dia kses 5 Oktober 2014).

Dilahur (1994) "Geografi Desa Dan Pengertian Desa Forum Geografi No. 14 dan 15 Th. VIII Juli dan Desember 1994.

Emzir. 2010.Metodologi Penelitian Kualitatif : Analisis Data. Jakarta: Rajawali Pers,

Hanny Purnamasari, 2018. "Manajemen Pemerintahan Desa Dalam Pembangunan Desa di Desa Lemahabang Kecamatan Lemahabang Kabupaten Karawang”.Jurnal Ilmu Pemerintahan ISSN 2442-5958 E-ISSN 2540-8674 Vol. 04, No.02, Oktober 2018. 
Loyalitas Kreativitas

Aldi Masyarakat Kreatif
P-ISSN 2722-2101, E-ISSN 2722-4201

Program Studi Ekonomi Manajemen Universitas Pamulang

Jurnal LOKABMAS Kreatif Vol.02,No.01,Maret 2021 Hal.100-109

Email:jurnalkreatif.manajemen@gmail.com https://pegiringan.desa.id/potensidesa/\#page-content

\section{https://www.desapedia.id/ruu-}

pengembangan-dava-saing-daerahupaya-dpd-ri-mendorong-daerahsemakin-kreatif-dan-inovatif/

Ikbal Mohamad. 2004. Mampukah KUD Mengubah Nasib Petani Universitas Negeri Gorontalo (UNG).

Miftakhul Hudadan Eko Budi Santoso, 2014. "Pengembangan Daya Saing Daerah Kabupaten/Kota di Propinsi Jawa Timur berdasarkan Potensi Daerahnya "Jurnal Tehnik Pomits Vol. 3, No. 2, (2014) ISSN: 2337-3539 (2301-9271Print)000

Milles, B Matthew \& A. Michael Huberman.2005. Analisis Data Kualitatif. Jakarta. UI Press

Peraturan Menteri Dalam Negeri Republik Indonesia Nomor 20 Tahun 2018 "Pengelolaan Keuangan Desa.Jakarta

Sugiyono.2010 “ Definisi Penelitian Kualitatif'. Bandung: Alfabeta

Sugiyono,2013.MetodePenelitianKuantitatif danKualitatif,CetakanKeenam

Belas.Bandung.

Sutikno, 2007. "Analisis Potensi dan daya Saing Kecamatan Sebagai Pusat Pertumbuhan Satuan Wilayah Pengembangan (SWP) kabupaten Malang".Journal of Indonesian Applied Economics Vol.1 No.1 Oktober 2007, 117.
Undang-Undang No.22 Tahun 1999 "Desa Dan Pemerintahan Desa"

Undang-Undang Nomor 6 Tahun 2014 "Desa Dan Pemerintahan Desa"

Undang-Undang Nomor 20 Tahun 2019 “

Undang-Undang Nomor 32 tahun 2004 "Pemerintahan Daerah"

\section{www.peraturan.go.id}

\section{www.Porlapdikti.go.id}

www.Kemendibud.go.id

https://pintek.id/blog/manajemen-keuangan/

\section{DOKUMENTASI FOTO KEGIATAN}
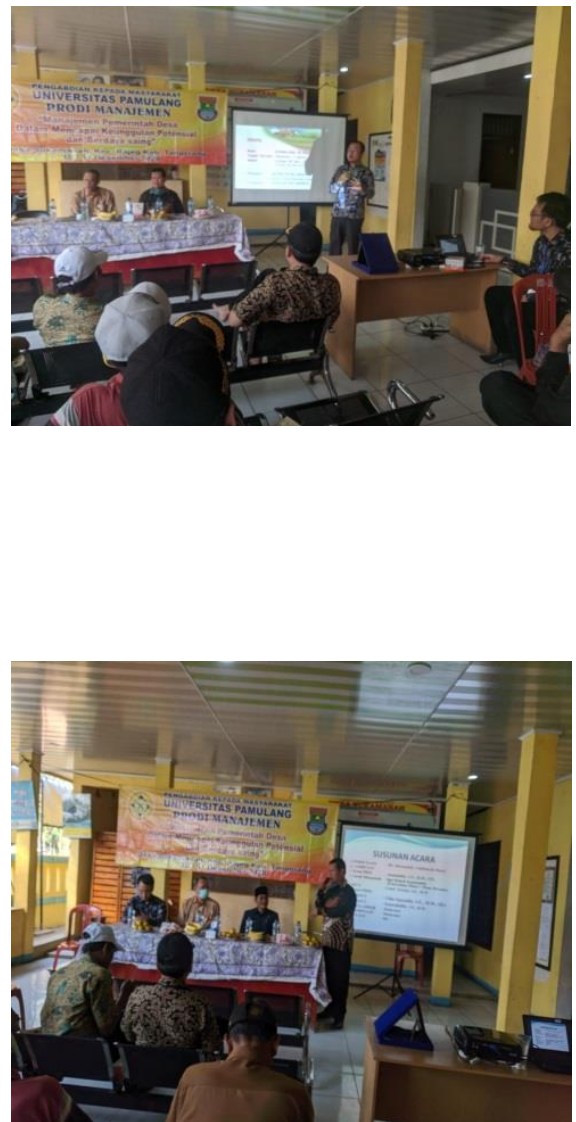
Loyalitas Kreativitas

Aldi Masyarakat Kreatif
P-ISSN 2722-2101, E-ISSN 2722-4201

Program Studi Ekonomi Manajemen Universitas Pamulang

Jurnal LOKABMAS Kreatif Vol.02,No.01,Maret 2021 Hal.100-109

Email:jurnalkreatif.manajemen@gmail.com
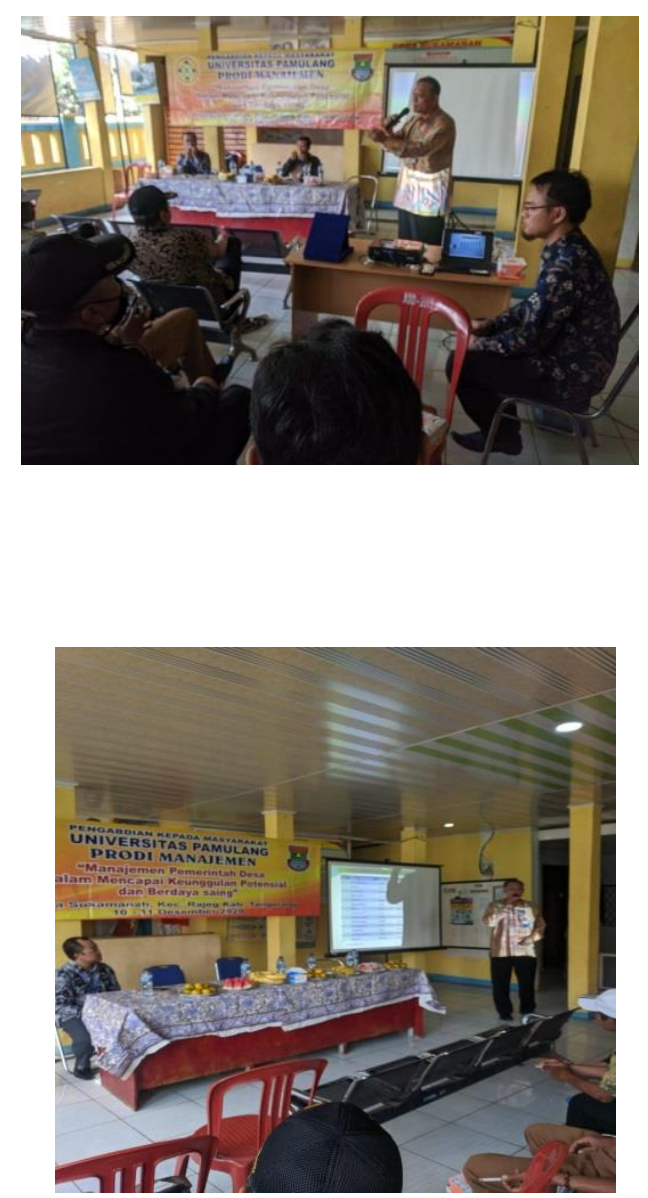